\title{
JAVANESE ISLAMIC ARCHITECTURE: ADOPTION AND ADAPTATION OF JAVANESE AND HINDU-BUDDHIST CULTURES IN INDONESIA
}

\author{
Noor Cholis IDHAM (1D* \\ Universitas Islam Indonesia, Yogyakarta, Indonesia \\ Received 22 October 2020; accepted 14 January 2021
}

\begin{abstract}
Javanese Islamic architecture appears to be highly influenced by previous cultures, even though Islam has brought a new civilisation since the 13th century in Indonesia. The classical mosques and houses seem to follow Javanese and Hindu-Buddhist principles in their buildings, elements and spatial arrangements. This paper examines how the Javanese adapted their architecture to meet Islamic values while preserving their previous traditions. The concept of architectural synchronisation in Javanese architecture is examined from the traces observed in the temple dioramas, depictions of contemporary cultural products, and several traditional buildings. The adoptions and adaptations that appear in some significant objects such as old mosques and houses are traced back to previous transformation principles. Architectural harmonisation for new needs seemingly bases on religion as the most potent driving aspect. However, what is interesting is that in the case of Java, embracing a new religion does not mean forgetting existing traditions. On the other hand, the principle of acculturation has created a peaceful transition in architecture. Some evidence suggests that Javanese high culture, such as the classical grand mosque and the joglo house, succeeded in translating Javanese and Hindu-Buddhist ideas into Islamic architecture in very distinctive ways.
\end{abstract}

Keywords: Javanese architecture, Javanese mosque, Javanese house, Islamic architecture, architectural acculturation.

\section{Introduction}

About 40 per cent of Indonesians are Javanese, living in Central Java, Yogyakarta and East Java. Before they converted to Islam, Javanism or Kejawen, Hinduism and Buddhism were common religions until the $13^{\text {th }}$ century. The Javanese immediately accepted the new beliefs, but they respected all by absorbing and incorporating teachings. Javanese people are open-minded to change but at the same time, maintain previous norms and traditions (Geertz, 1960, p. 355; Mulder, 1997, pp. 41-49). Adopting old and new habits were preferable over cessation and eradication since they could not quickly move on from the earlier customs. The new practice widely spread in terms of religion and other aspects of life, which unfortunately fails to uphold inclusive Islam principles. The distinctive feature of Islam in Java, which is unique and different from "formal" teachings, gave birth to "Javanese Islam" (Boogert, 2015). It could not eliminate Javanism and Hinduism-Buddhism, including using their architecture ideas (Prijotomo, 1988).

The Javanese architectural discourse regarding mosques and houses is very complicated. H. J. De Graaf (1899$1984)$ and Th. Pigeaud (1899-1988) assumed that mosques in Java were influenced by Indian and Chinese pagodas, while G. F. Pijper (1893-1988) hypothesised that they were inspired by Hindu and Buddhist temples (Njoto, 2015). However, Ahmet Wahby's related studies concluded that even Hindu-Buddhist ideas and realms could not contribute to mosque architecture (Wahby, 2007). Ashadi found some architectural syncretism from Javanism-HinduismBuddhism at the Demak Mosque as the first grand mosque in Java (Ashadi et al., 2015). These wide-variety findings are exciting but at the same time increasing the ambiguity in the field over time. Moreover, throughout history, borrowing and modification architecture ideas demonstrate accommodation and synchronisation of old and new customs. The Indonesian archipelago has witnessed the fusion of different cultures from many races over the centuries (Widodo, 2012). Since Islam is the main religion, Islamic principles should logically act as the most influential factor but not so in reality, including the architecture.

Architectural adoption and adaptation as a form of cultural acculturation done by the Javanese became very interesting. The religious transition occurred smoothly so that physical differences may not be easy to be recognised.

*Corresponding author. E-mail: noor.idham@uii.ac.id 
Thus the study in the early mosques and houses is essential to improve our understanding of Islamic architecture in Java. To distinguish the most influencing factors in architecture development between Javanism, Hindu-Buddhism, and Islam, we investigate some of the hidden signs laid in some crucial objects to reveal the relationship. The examination applied for properties of the objects to discover the original features from their predecessors and how it is synchronised. Comparisons with similar buildings preserved by "native" users, such as those found on Bali's island, are also meaningful. Discussion on the ancient Balinese root is also worthwhile because they mostly tied from the Javanese-Hindu who migrated and still have the opportunity to maintain their culture. Furthermore, assessments of old buildings depicted in several artefacts, such as house figures on the classical temple's stone carvings or dioramas, and house illustration on wayang are also meaningful.

\section{Islam penetration in Java}

Islamic civilisation in Indonesia started with the appearance of the Sultanate of Pasai in Northern Sumatra in 1292. Two-and-a-half centuries later, Islam penetrated Java mostly through trading involving relatively less violence than other places (Abdullah et al., 2018; Marwoto, 2016). The new religion then spread widely and generated several Islamic kingdoms starting with the Sultanate of Demak (1475-1554), Pajang (1568-1586), Mataram
(1587-1755), to Surakarta (1745-recent) and Yogyakarta (1755-recent). Majapahit (1253-1527) was the last Hindu kingdom in Java which was proceeded by the Sultanate of Demak, led by a sultan who was the descendant of Barwijaya V, the last king of Majapahit (Marwoto, 2016). They converted most of the Javanese to Islam quickly, supported by the nine Islamic saints Wali Sanga regarding the local cultures (Lücking, 2014). Wayang kulit or shadow puppet converted from India's Ramayana stories to Islamic thoughts was one of their Islamisation methods within the culture. They also invented new systems such as omitting the social classification, which was practical in Hinduism; replacing zoomorphic figures with floral and geometric patterns; and devising a Javanese calendar based on the Hijri (Aulia, 2009).

Meanwhile, Hindu-Buddhism was not necessarily extinct, but rather, preserved by moving their centre to Bali Island. Many of the Javanese Hindu, who insisted on keeping their remaining religion, including the princes, escaped to the next island, where they continue to practice their religion and cultures (Munandar, 2011). Up to the recent time, Balinese ethnography is the classical Indonesian time-capsule where the Majapahit's culture still flourishes, including architecture. Nevertheless, in Java, their historical traces remain permanently in a time-capsule of wall-relief in many temples such as Borobudur (770), Prambanan (850), Jago (1268), or Sukuh (1437). Some of them even illustrate the building cultures in detail, which are no longer exist in Java (Figure 1).
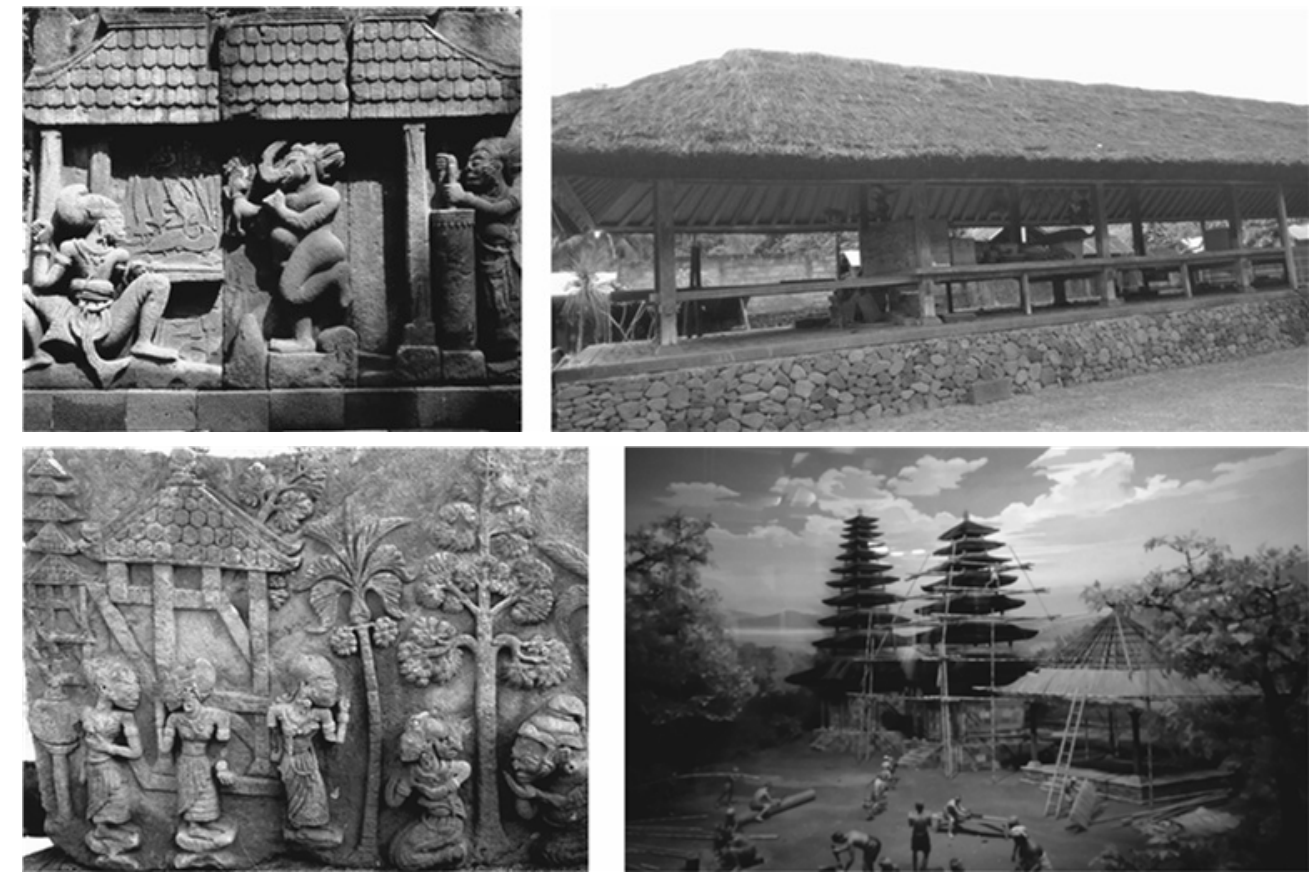

Figure 1. The long hip roof building in Sukuh temple relief and the recent construction in Bali (above) and the pyramidal roof with the background of the pura in the reliefs and Bali (below) (photos: author) 


\section{Architectural acculturation}

The mosques in Java show the adaptation and acculturation of many cultural contexts that characterise its architectural development. Firstly, they used a pyramidal roof with timber post and beam, which is broadly known to be inspired by the earlier building tradition of Hinduism and Javanism: bale. Secondly, they then have continued with Arabic domes style with a metal or reinforced concrete shell. Lastly, they are trying to accommodate all types to show the adaptability. In the classical time, Demak Mosque (1466) is the oldest great mosque followed by the more acculturated style of the Kudus Menara Mosque (1549) which combines the pyramidal roof and a dome. In the modern era, the architecture of national mosque Istiqlal Jakarta (1961), designed by the competition winner Cristian architect, became a new stream with a modern dome. Dome architecture was also assumed due to Arabisation that made Javanese-Muslim more orthodox and pious (Lücking, 2014). Several attempts to integrate the older and newer styles in the mosque's architecture were also carried out. The Great Mosque of Central Java (2002) in Semarang shows this eclectic effort by combining the pyramidal roof and four minarets (Figure 2).

In domestic architecture, the Javanese house still follows ancient cultures, such as in recent joglo and limasan houses. These houses demonstrate a combining character between the older principles and new streams of thought. The vernacular houses are also ordinarily associated with the previous traditions since they mostly accommodate the local customs of Javanism or Kejawen. However, many clues suggest that the joglo's spatial configuration and its formal appearance express some Islamic ways such as converting the offering place or mid-bedroom to a praying room and using a vegetative figure instead of human and animal figures. Nevertheless, they all should be considered Islamic architecture since they are in a Muslim country (Grabar, 1978); thus, all aspects that are inappropriate with the Islamic ways should be replaced. This development was associated with the new needs of daily living, which had been gradually affected by Islam (Figure 3 ).
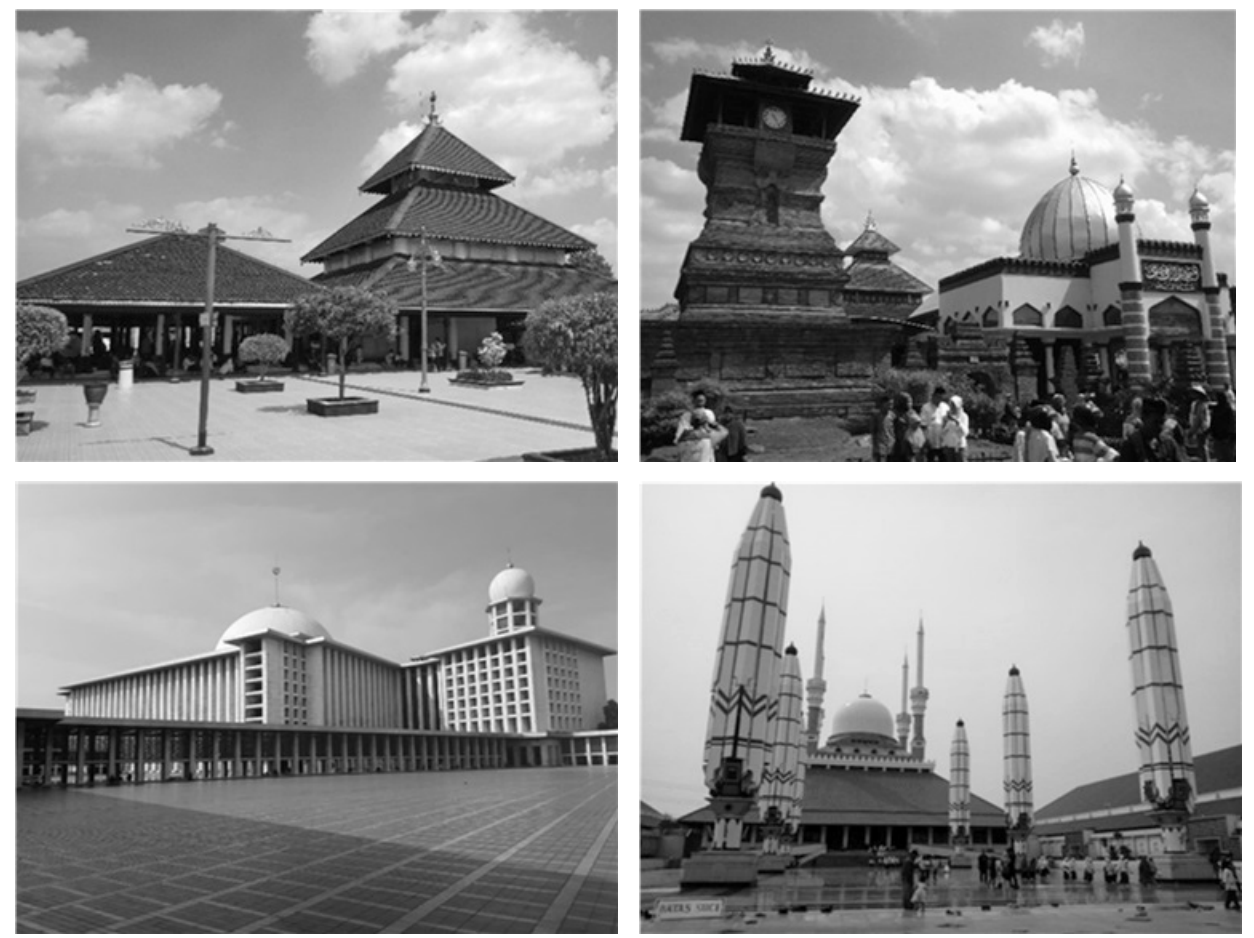

Figure 2. Javanese mosques from the older to newer: Demak (left-top), Kudus (right-top), Jakarta (left-bottom), and Semarang Great mosques (right-bottom) (photos: author)
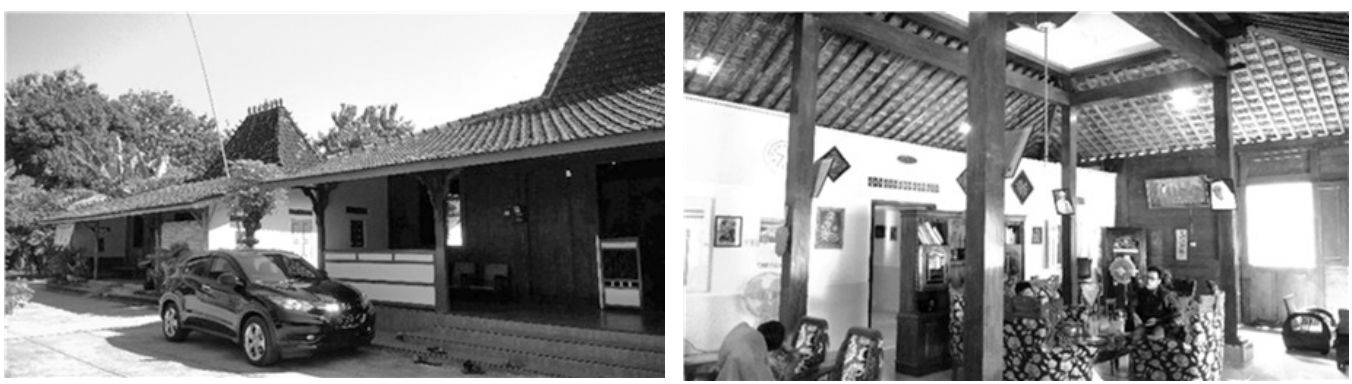

Figure 3. Joglo house exterior and interior appearances (photos: author) 
Islam's dispersion age had influenced Demak and $\mathrm{Ku}-$ dus's magnificent mosques in the $15^{\text {th }}$ and $16^{\text {th }}$ century to Yogyakarta and Surakarta's royal palaces in the $18^{\text {th }}$ century. In Indonesia, Islamic culture was broadly acknowledged outside the domestic architecture and focused only on mosques, castles, and other essential buildings (Sumintardja, 1978). Nevertheless, the Islamic traces on the houses are faintly visible since Muslim had been living in them. Conversely, Islam in Java did not propose the introduction of an entirely new building tradition; instead, the existing architectural forms were appreciated and reinvented or reinterpreted to suit Muslim requirements. This method brought an architectural harmony by a unique style which has never been found in any other Islamic regions (IZMD, 2018). Adopting previous-local customs was a crucial method in spreading Islam in the archipelago (Abdullah et al., 2018). The mystical thought by the Sufis, who aim for harmonious syncretism, also had contributed to the architectural acculturation by adjoining one to another style and avoiding the cultural shock of the recent tradition.

\section{The early mosques and their architectural acculturation}

The Demak Mosque (1466) was the first royal mosque in Java to adapt the native building customs to Muslims' needs. Led by the first king, Raden Patah, one of the princes of Hindu King Brawijaya V, together with the board of Islamic missionaries or Wali Sanga, decided to build the mosque a while after the initiation of the sultanate and the weakening of the Hindu-Buddhism Majapahit. According to the massive building's previous local tradition, the mosque was built similar to Balinese wantilan which incorporates an inclined-elevated roof supported by wooden posts and beams. The site was chosen just near the city's square representing Hindu-Buddhist's Mandala in the distinctive urban pattern. It was followed broadly by almost every classical Islamic towns in Indonesia (Marwoto, 2016). However, the mosque's location on the west side of the square corresponds to the Qibla direction and the mosque's front yard as the prayer space extension. This configuration perfectly matches the mosque function, especially the need for open space in special holidays massive praying.

A three-level pyramidal roof covers the main prayer building, supported by the four high wooden columns called the saka guru in the centre, with 19.54 meters in height and 1.45 meters in diameter. These four giant pillars were such invention since they had never been applied before, neither in the Balinese wantilan nor in the pagoda-like tower Balinese pura. Those belonging to wantilan have never reached this height since the roof is lower. To achieve the mosque's required size, even the Javanese devised a unique "laminated" wood in one of the columns made from pieces of wood glued and tied together. This column seems like the oldest laminated wooden technique in Indonesia. The secondary columns series surrounding the saka guru bears the second-tier roof, and the outer columns support the third-tier roof. This structural arrangement was quiet new and apparently not been applied either before in Majapahit or recently in Bali.

The hip roof of mosque veranda, brought from one of the Majapahit palaces, indicates how great their structure was. Eight pillars called saka Majapahit, or Majapahit's columns construct the structural system of the front hall. It was aimed to show that the Demak Sultanate had deserted to inherit the previous great kingdom and has a right to continue with the Islamic ways (Zaki, 2017). However, the front hall columns' size is much smaller than the saka guru used in the main prayer hall. Thus the configuration tells us that the earlier significant structures were not as enormous as those involved in the mosque. This fact proves that the mosque structure had been developed for Islamic culture by the considerable improvement from the previous building.

Kudus Menara Mosque (1549) was built 80 years after the Demak, resembling a Hindu temple or candi adapted for a new function as a drum tower for calling prayer times. This mosque was also the work of one of the Islamic missionary board Wali Sanga; Jafar Shadiq, or Sunan Kudus. He was one of the prominent members who strongly teach to adopt rather than to replace HinduBuddhism culture. His mosque bore a resemblance to the Great Mosque of Demak. The mosque is accompanied by a unique minaret similar to the temple of Majapahit in eastern Java or Bale Kulkul as the Balinese temple's bell tower (Figure 4). Besides accommodating the azan, the tower also hosts the drum and wooden bell kentongan or kulkul to signal the prayer times. However, Roesmanto argued that the tower is different from Bale kulkul, and its configuration is not similar to any temples in Java (Roesmanto, 2013). The drum itself was a new tool discovered by Javanese Muslims, neither used in the Javanese Kejawen nor Hindu-Buddhism.

If the Demak Mosque has Majapahit columns in the veranda, the Kudus mosque has the Majapahit entrance gate called gapura or bentar. The gate which was constructed from bricks resemblances the former kingdom property located inside the prayer hall. The gapura was a basic-common element in a Hindu temple complex, defining the space's secrecy and hierarchy. Before the additional construction of the veranda, the gapura was located in front of the main prayer hall outside the mosque. Since the later enlargement of the mosque, both of the gapura are now inside the mosque. The gate was also meant to symbolise that anyone wishing to pray in the mosque would enter a state where his mind and soul were at a level of having sincere intentions to face God. The Kudus mosque became more interesting with the late addition of metal dome above the front hall in 1933 (Akbar, 2010) where most of the mosque was still utilising the pyramidal roof. The mixed style between pre and Islamic era shown by the drum tower and a pyramidal roof combined by the dome is the manifestation of local and global acculturation in the 

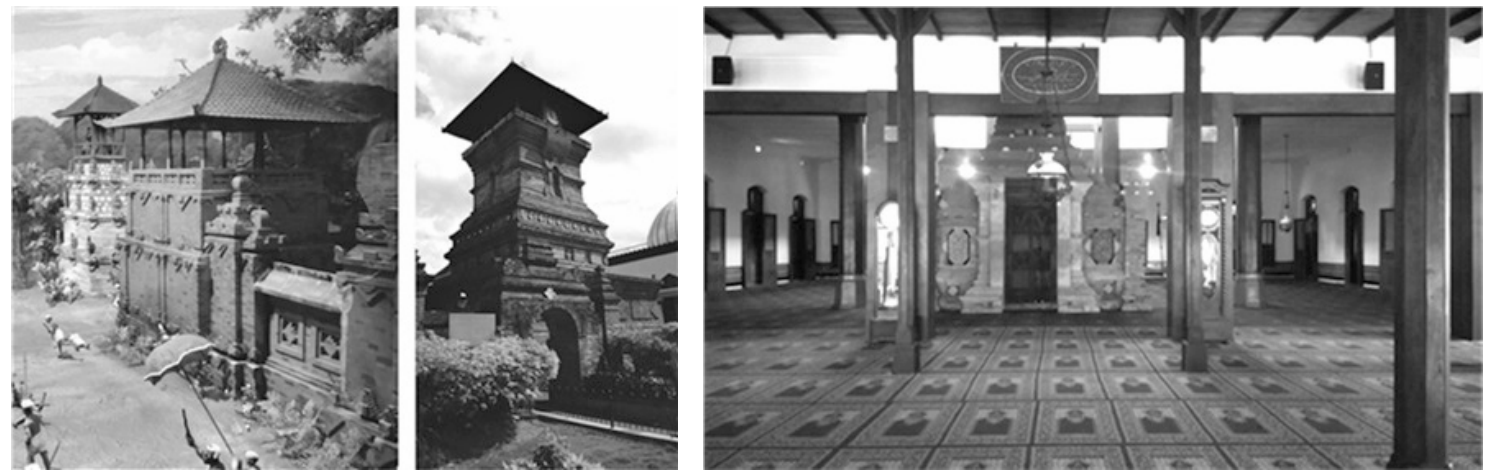

Figure 4. Bell tower of bale kulkul Bali (left), the drum tower of Kudus Menara Mosque (centre), and the temple gate in the mosque interior(right) (photos: author)
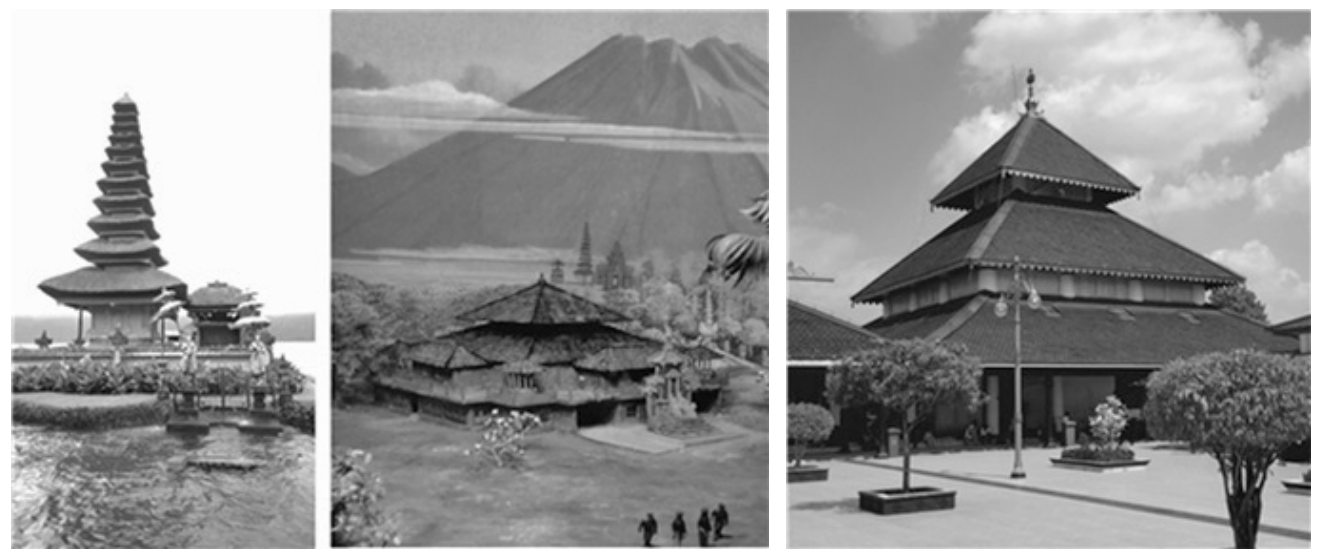

Figure 5. The Balinese pura (left) and wantilan (middle) have been adopted by the three tiers roof of Demak mosque (right)

mosque at the first appearance. The configuration represents the synchronisation between the previous and recent religious notions and the traditional and modern stream in architecture (see Figure 2).

Yogyakarta Great Mosque (1773) is one of later Javanese mosques where the Islamic monarchy still exists, in the Yogyakarta Sultanate. The mosque appears more significant tough yet similar to the Demak and Kudus mosques for the three-tiered pyramidal roofs with a double-layered roof on the terrace. The four high columns support the main hall space with buttresses-like secondary and tertiary series of columns surrounding. Lately, it became the commons structural configuration for a great mosque to deal with earthquake risks. The veranda, which is enriched from the other classical mosques, has eight colourful decorated pillars. A piece of a stone base which follows a particular floral pattern called the Padma supports the pilaster. In the post itself, a floral profile called Putri Mirong is carved and coloured in contrast. Arabic calligraphy as the sign of "Muhammad" and "Allah" are hidden behind both patterns to avoid improper use of the names (Idham, 2017). Pawestren or a particular prayer space for women has emerged in the mosque as a new facility which was never available before (Aryanti, 2006). A shallow pool lies across the entrance side for washing the worshipers' feet before entering the mosque.
It can be argued that the earliest Javanese mosques are unique examples that took their inspiration from the existing building tradition. The previous experiences in architecture had shaped the Javanese's understanding (Vasilski, 2016). The four central-high posts thus triggered a more progressive mosque architectural form. The mosque's architecture became incomparable with an elevated multi roof structure of pura, as the Hindu-Balinese temple's main section where the worshiper usually stands outside. In the sense of monumentality, a pura may inspire the mosque by its tiered roof, though not as much as it has by three, five, seven, nine, or eleven layers. Instead, the Javanese classical mosques could be related to the public facility used before; the Balinese wantilan (Figure 5). This multi-function hall now commonly still exists in a Balinese temple complex with double-tier roof layers. They are built either with a square or rectangular plan accompanied by a pyramidal or hip roof. The mosques and wantilan share a similar function as a gathering hall that can accommodate many people under its roof.

Though seemingly indistinguishable, the Javanese mosques and Balinese wantilan have different approaches both in spatial and structural systems. If the wantilans utilise either a square or rectangular plan with a single open mass, they only employ a square floor. Mosque roof is always a pyramidal Tajug with the enclosed main hall and 


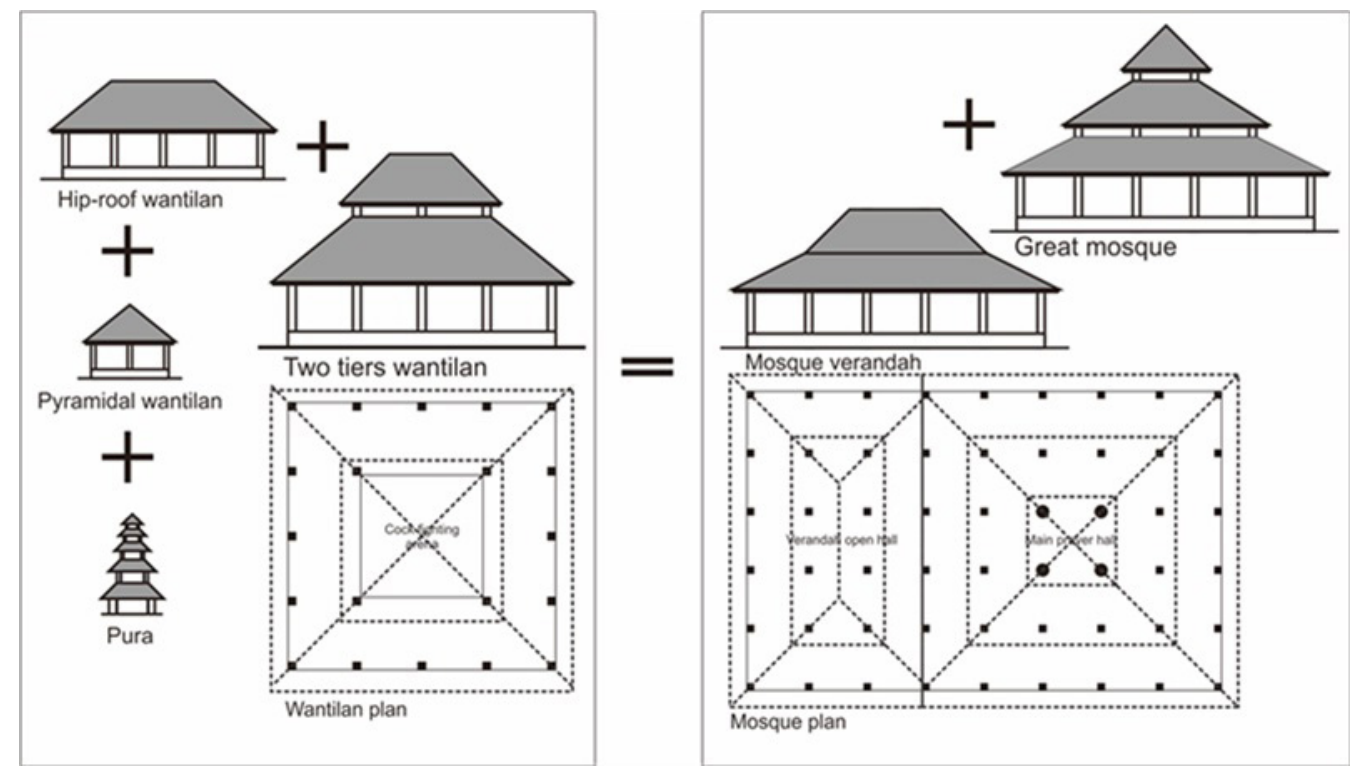

Figure 6. Mosque as a result of the combination forms of pura, pyramidal roof, and two tiers roof of Wantilan (drawings: author)

enlarged with front open veranda while wantilan may use either pyramid-like or hip roof (Figure 6). Instead of using the elongated plan in a single building mass, a mosque assesses the additional space's mass configuration. The front hall utilises a hip roof, either in a single or double layer, with a rectangular plan that serves an extended prayer space and a multi-function facility. Four columns in the main prayer hall support the central tall-roof in three levels, which are not used in the wantilan. Some alterations, yet both share post and beam wooden frame in the main four-column saka guru, were inherited from the previous building tradition. However, the stepped roof still picturing the importance of the religious building just seen in Hindu-Buddhist temples. The value of the formal-vertical hierarchy is seemed universal language of religious building disregarding the religion itself. A smooth synchronisation in religious architecture was also enriching the freedom of architectural harmony.

As depicted both in the temple's reliefs and in the shadow puppet opening screen of gunungan, the pyramidal or hip roof and two-tier roof were the customary structural forms instead of three tiers (Figure 7). The two-tier roof represents the most important buildings in the era where the mosque's three-level roof had not yet been discovered. The skin puppet was created in the period of very early Islamisation as one of the missionary tools, thus whatever depicted on the characters should have been taken before Islamic age. Thus, the extension of the three-level roof is strongly argued to result from Islamic architecture development in the era. It is therefore associated with the three-level of spiritual achievement in Islamic spiritual achievements as Iman (faith in God), Islam (safe life by
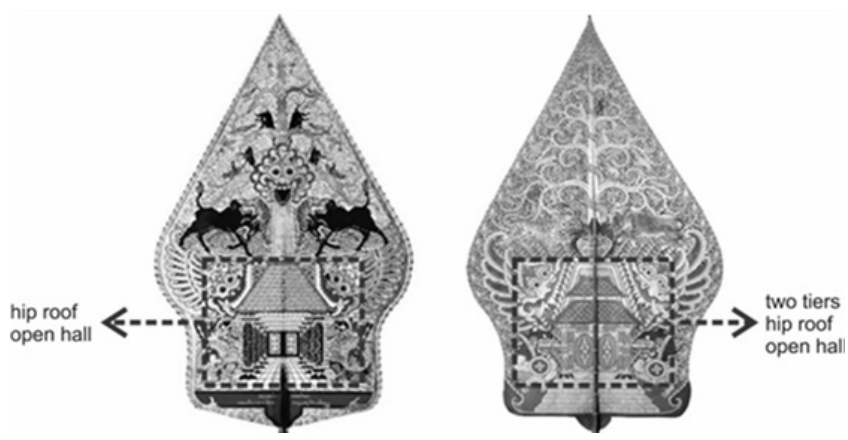

Figure 7. The building type is depicting in the gunungan of the Javanese shadow puppet background: hip roof and double layer hip roof (photos: author)

following the guidance sharia), and Ihsan (attaining spiritual perfection).

A building without stilts was also another new emergence characteristic compared to the previous building found in the temple's reliefs, mostly elevated by floor layer above the ground. Most of the great mosques in Java, unlike Balinese wantilan, have been developed without stilt hall. The fact that Java Island tends to be drier as we move east, stilt houses are generally more built preferably in the west than in the east of Java. Bali Island is in the eastern area next to Java Island means that elevated Balinese building on stilts, including the wantilan, was initially brought from Java. This certainty leads us to understand that the classic Javanese great mosque was developed further because of the ability to bear many prayers. Therefore we can still find the smaller mosque or mushalla with stilt floor in Central and East Java. 


\section{Javanese houses as part of Islamic architectural synchronisation in Java}

The kampung, limasan, and joglo are the Javanese house forms typology stretching from the very simple to the most complex structures. The joglo is the most advanced and complicated roof since it represents the highest typology level (Idham, 2018) (Figure 8). It also depicts the outstanding achievements in economic, social, environmental, and technical development in architecture (Prijotomo, 1988; Ronald, 1988; Satwiko, 1999). The joglo is commonly associated either with Javanism or the syncretised culture of Javanese Hindu-Buddhism. Nevertheless, it is also suspicious that the recent appearance of joglo was never found in the previous civilisations before Islam penetrated Java Island in the $15^{\text {th }}$ century. Besides inheriting from the earlier culture, several proofs indicate that this style is part of Java's Islamic culture. This circumstance may tell us that the religious syncretism stepped forward to domestic life as architectural synchronisation.

The joglo house had flourished in Java, but which civilisation period had broadened its popularity is open to speculation. The name of joglo has borrowed from tajug loro, which means a doubled tajug, the pyramidal roof house, which was broadly used before (Kartono, 2005). Conversely, the Majapahit houses were utterly different from those recently known in Java (Munandar, 2011). Although it is undeniable that the development was based on the previous achievement in traditional architecture, the recent form was mostly the later civilisation work. This position is also supported because none of all 77 buildings depicted in the reliefs scattered on many temples uses the joglo roof but limasan and tajug (Rahmi, 2015). Joglo does not appear on the reliefs of Prambanan, Hindu's sanctuary in Yogyakarta built in the $9^{\text {th }}$ century, and any other tem- ples in Java Island (Satwiko, 1999). Although some of the older house development principles are still implicated, such as multi-layer roof, the joglo house uses a considerably different roof type. Unlike in the wantilan or mosque, where the multi inclined roof performs direct ventilation, the joglo have no opening between the roofs. Instead, the buoyancy effect on the multi-sloped roof and perforated wooden materials on the building envelope are fairly enough to circulate the heat in the air (Idham, 2018).

Instead of joglo, the building type of limasan and tajug were popular roof styles used in the pre-Islamic era discovered in wayang as illustrated in the gunungan, the Javanese opening screen shadow puppet. As well-known for its dominant feature, the absence of joglo may tell us that it had never been implemented before or was not yet already widespread. Most likely, the style appeared in the later era as the result of the Islamic culture development corresponding from the previous traditions. The houses are also never found in Bali where preserved Majapahit practices are still available. Therefore, the joglo can be considered one of Islam's peak cultural achievements after spreading in Java.

The other reason why the joglo is more associated with Islamic culture than the others can be traced to the house's spatial organisation. In its most completed formation, which is mostly organised from four building masses (Cahyono et al., 2017), they are utilised differently related to the later needs. The first and second masses comprise an open hall pendapa in the front for a formal gathering, and an enclosed space or dalem in the central area for private family matters. The others are two additional building masses on both the rear-left and right sides for service area purposes. The first and second building masses commonly utilise the joglo or limasan type where others use the simple limasan or kampung. The open hall in the front

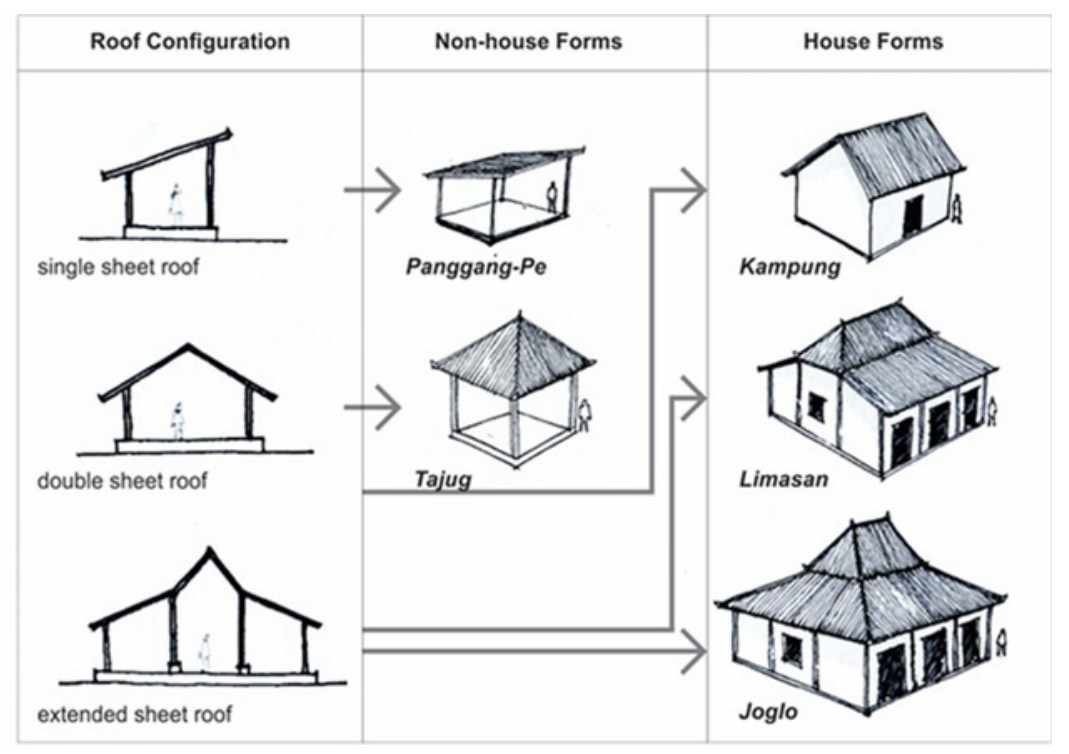

Figure 8. A typical plan of completed Joglo houses and form-spatial arrangement (drawings: author) 

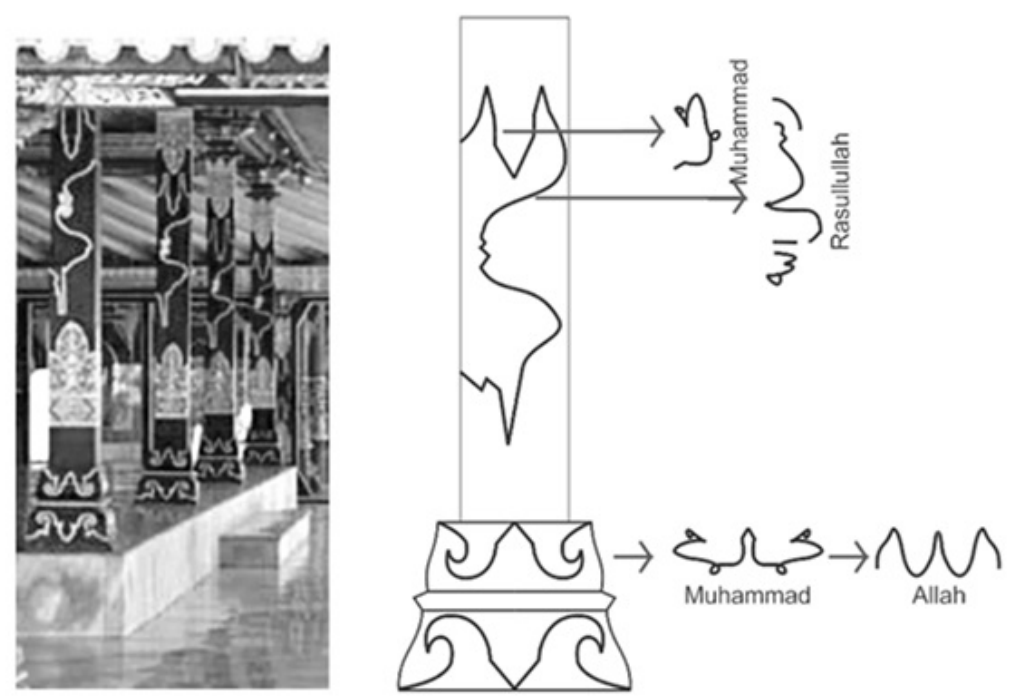

Figure 9. The spiralling pattern of Putri Mirong in columns and its' base as a calligraphy of Allah and Muhammad (Idham, 2017)

serves as a reception area for guests and formal gatherings, generally for men. The enclosed room provides space for family members, especially women. Although it does not apply strictly in daily living, this spatial segregation based on gender is considered mostly from Islamic culture.

The concept of three separate bed-rooms also aims for gender separation despite a husband-wife relationship. The husband occupies the right side and the wife on the left side while the centre bedroom is dedicated to a just married couple and mostly forbidden for any daily function except for praying. The previous tradition developed the three-bedroom concept, which was also commonly found either in limasan or kampung. In Javanism, the central room was dedicated to Dewi Sri, the goddess of fertility. Since most of Javanese have converted to Islam, the most sacred mid-room serves as a praying space or mushalla. Joglo also means to communicate with God by the area between the four columns representing four directions. It depicts the four steps of nafs of human mindfulness in Islamic teaching, starting from amarah, lawwamah, sufiah, and mutmainah (Subiyantoro, 2011). These four columns also correspond to Jibril, Mikail, Isrofil, and Ijro'il as the four principal angels in Islam.

The gender segregation originated in Islamic values was hardly found in the previous Javanism, Hinduism, or Buddhism culture. For Javanese, its aim was for more giving freedom to the women rather than restriction or more on an association rather than division (Aryanti, 2006). In the complete Joglo, the father's space or the masculine area in the right expands to an additional building mass in the west section. On that spot, the boys stay with farming tools and harvesting products. On the other side, the left spaces or pakiwan as the women's area extends from the mother's room to the left side zone. The feminine sections, such as cleaning space, kitchen utensils, and food materials, occupy this side. The host occasionally receives wom- en guests and relatives in this area. The enclosed dalem with left-field pakiwan are spaces devoted to women to protect them and give them freedom apart from the men. However, the women's sector is not forbidden to men. The family members and relatives might still access the space. By this organisation, Javanese Muslims have accepted the Islamic principles of modest ways up to the present day.

As found in the mosque, some of the Javanese houses also have the spiralling pattern of Putri Mirong, the floral decorative design in the columns or the stone base related to Islamic calligraphy. As the columns and its bases are the most crucial elements of the houses, praying to God, paying attention, and giving respect to the Prophet are obligatory in the building structure (Figure 9). Carving their names on the essential elements for safety and security is considered appropriate. It seems that only the JavaneseMuslim could develop such patterns as a combination of the decoration pattern and praying function in the house elements.

\section{Conclusions}

The vernacular architecture in Java shows harmony by adopting previous cultures and adapting it for new functions. Along with the penetration of Islamic religion, which was relatively non-violent, the freedom to follow the tradition was high. The surrounding existing Javanism and Hindu-Buddhist cultures had affected the mosques and houses in early Islamisation in Java. The recent gathering hall of Balinese wantilan has a strong connection with the classic mosque and directed the utilisation of the massive building for its function. Simultaneously, on the domestic side, the Javanese house of joglo appears to be the Javanese-Muslim development based on the preIslamic civilisation in Java. Both cases are established with distinguishing features found in the objects, depicted on 
the scattered mediums related to the classic objects, and revealed similarities from other comparable entities in Bali. It denotes that the culture, including the architecture, is always in progress, following the new needs in conjunction with the available resources and methods.

Javanese mosques with the four central columns supporting the three-tier pyramidal roof are a typical configuration involving the open veranda as space enlargement in the front section. From its existing form and structure, we can assure that they were borrowed from the wantilan. The development has been done by an accumulative technique combined with the new expression needed according to the further demands. Up to this stage, Javanese architecture could be considered a continuation and innovation of the previous cultures. For Javanese, the existing architecture and the culture seem to be better rooted in the local habits than immediate replacement by unfamiliar customs. Unfortunately, the modernisation in Islam, seen as a return to conservative teaching in sharia has also triggered a suggestion of importing the architecture. The countless modern mosques in Java nowadays imitate the Arabic styles assumed as "Islamic purification movement."

On the other hand, the joglo house has proven to be a cultural product of the Islamic era as Javanese Islamic architecture's masterpiece. It cannot be alienated from previous house types of kampung, limasan, and tajug. Continuous development from the earlier architecture had ended in a distinctive house type, which better corresponds to the newer needs while maintaining the traditions. However, since the traditional building styles were mostly based on beliefs rather than logical sense, the previous principles still obviously affected the architecture. This phenomenon was reinforced by the Javanese tendency to maintain ancient wisdom. These findings also discover the reason why the Javanese house, such as joglo is still associated with Javanism or Hindu-Buddhism.

\section{References}

Abdullah, A., Wekke, I. S., Hirth, F., \& Rockhill, W. W. (2018). Origins of Islam in Indonesia. International Journal of Pure and Applied Mathematics, 119(18), 1149-1179.

http://www.acadpubl.eu/hub/

Akbar, J. (2010). Habis tumpang terbitlah kubah - historia. https://historia.id/kultur/articles/habis-tumpang-terbitlahkubah-v2RZv/page/1

Aryanti, T. (2006). The center Vs. The periphery in central- Javanese mosque architecture. Dimensi Arsitektur, 34(2), 73-80.

Ashadi, Antariksa, \& Salura, P. (2015). Syncretism in architectural forms of Demak Grand Mosque. Journal of Applied Environmental and Biological Sciences, 5(11), 26-30.

Aulia, F. M. (2009). MASJID: form of manifestation of art and culture. El Harakah, 11(1).

https://doi.org/10.18860/el.v1i1.420

Boogert, J. van den. (2015). Rethinking Javanese Islam. Towards new descriptions of Javanese traditions [Doctoral thesis]. Leiden University. http://hdl.handle.net/1887/36400

Cahyono, U. J., Setioko, B., \& Murtini, T. W. (2017). Transformation of form in the growth of modern Javanese house in Law- eyan Surakarta. Journal of Architecture and Urbanism, 41(4), 288-295. https://doi.org/10.3846/20297955.2017.1411848

Geertz, C. (1960). Religion of Jawa. The University of Chicago Press.

Grabar, O. (1978). The formation of Islamic arts (3rd ed.). Yale University.

Idham, N. C. (2017). Joglo House, an Islamic architecture legacy of eastern-tropical world [Conference presentation]. International Conference on Protecting Cultural Heritage of the Muslim World. OIC-IRCICA-ISESCO.

Idham, N. C. (2018). Javanese vernacular architecture and environmental synchronisation based on the regional diversity of Joglo and Limasan. Frontiers of Architectural Research, 7(3), 317-333. https://doi.org/10.1016/J.FOAR.2018.06.006

IZMD, H. K. (2018). Javanese timber architecture wooden architecture in Java-archismoasia. https://sites.google.com/site/archismoasia/home/timber_architecture

Kartono, J. L. (2005). Konsep ruang tradisional Jawa dalam konteks budaya [The Javanese traditional space concept in cultural context]. Dimensi Interior, 3(2), 124-136. https://www. neliti.com/publications/217877/konsep-ruang-tradisionaljawa-dalam-konteks-budaya

Lücking, M. (2014). Making “Arab” one’s own: muslim pilgrimage experiences in Central Java, Indonesia. Internationales Asien Forum. International Quarterly for Asian Studies, 45(1/2), 129-152. https://search.proquest.com/docview/1628647317/ fulltextPDF/AAEA1BBEC2364F94PQ/7?accountid=62100

Marwoto. (2016). Spiritual phenomena in the Town of Demak. Procedia - Social and Behavioral Sciences, 227, 451-457. https://doi.org/10.1016/J.SBSPRO.2016.06.100

Mulder, N. (1997). Inside Indonesian society: an interpretation of cultural change in Java. The Pepin Press B.V.

Munandar, A. A. (2011). Pakuwon pada masa Majapahit: kearifan bangunan hunian yang beradaptasi dengan lingkungan [Pakuwon in Majapahit era: housing adaptation to the environment]. In The 5th ICSSIS International Conference on Indonesian Studies (pp. 36-52). Yogyakarta. https://icssis.files. wordpress.com/2012/05/1819072011_05.pdf

Njoto, H. (2015). On the origins of the Javanese mosque. The Newsletter, 72. https://www.iias.asia/the-newsletter/article/ origins-javanese-mosque

Prijotomo, J. (1988). Ideas and forms of Javanese architecture. Gadjah Mada University Press.

Rahmi, D. H. (2015, November). Bangunan rumah pada relief Candi Borobudur [House in Borobudur temple relief]. Arsitektur Dan Lingkungan UGM. http://arsitekturdanlingkungan.wg.ugm.ac.id/2015/11/21/bangunan-rumah-pada-reliefcandi-borobudur/

Roesmanto, T. (2013). Rupa bentuk Menara Masjid Kudus, Bale Kulkul dan Candi [Formal apperance of Minaret Mosque Kudus and Balinese Bell Tower Temple]. Jurnal Arsitektur Universitas Bandar Lampung, 1(4), 28-35. http://jurnal.ubl.ac.id/ index.php/ja/article/view/459/439

Ronald, A. (1988). Manusia dan rumah Jawa [Javanese and their houses]. JUTA UGM.

Satwiko, P. (1999). Traditional Javanese residential architecture designs and thermal comfort. A Study using a computational fluid dynamics program to explore, analyse, and learn from the traditional designs for thermal comfort [Doctoral thesis]. Victoria University of Wellington. http://researcharchive.vuw. ac.nz/xmlui/handle/10063/417

Subiyantoro, S. (2011). Rumah tradisional Joglo dalam estetika tradisi Jawa [Joglo traditional house in Javanese aesthetic]. 
Bahasa dan Seni, 39(1), 68-78. http://sastra.um.ac.id/wpcontent/uploads/2012/01/7_-Slamet-Subiantoro.pdf

Sumintardja, D. (1978). Kompendium sejarah arsitektur [Compedium of architectural history] (2nd ed.). Yayasan Lembaga Penyelidikan Masalah Bangunan.

Vasilski, D. (2016). On minimalism in architecture - space as experience. Spatium, (36), 61-66. https://doi.org/10.2298/SPAT1636061V

Wahby, A. E. I. (2007). The architecture of the Early mosques and shrines of Java: influences of the Arab merchants in the 15th and 16th centuries? [Dissertation]. Bamberg University.

http://www.sabrizain.org/malaya/library/architecturejava.pdf
Widodo, J. (2012). Urban environment and human behaviour: learning from history and local wisdom. Procedia - Social and Behavioral Sciences, 42, 6-11. https://doi.org/10.1016/J.SBSPRO.2012.04.161

Zaki, M. (2017). Kearifan lokal Jawa pada wujud bentuk dan ruang arsitektur masjid tradisional Jawa (Studi kasus: Masjid Agung Demak) [Javanese local wisdom in the traditional mosque architectural form and space]. Universitas Diponegoro. http://eprints.undip.ac.id/60450/ 